\title{
Physicochemical Properties and Carbon Storage of Forest Soils on Cambodian Basalt: A Preliminary Study with a Density Fractionation Approach
}

\author{
Jumpei TORIYAMA ${ }^{1 *}$, Seiichi OHTA ${ }^{2}$, Yasuhiro OHNUKI', \\ Akihiro IMAYA ${ }^{1}$, Eriko ITO ${ }^{3}$, Mamoru KANZAKI ${ }^{2}$, Keizo HIRAI, \\ Makoto ARAKI ${ }^{1}$, Yoshiyuki KIYONO ${ }^{1}$ and Sophal CHANN ${ }^{4}$ \\ ${ }^{1}$ Forestry and Forest Products Research Institute (FFPRI) (Tsukuba, Ibaraki 305-8687, Japan) \\ ${ }^{2}$ Graduate school of Agriculture, Kyoto University (Kyoto, Kyoto 606-8502, Japan) \\ ${ }^{3}$ Hokkaido Research Center, FFPRI (Sapporo, Hokkaido 062-8516, Japan) \\ ${ }^{4}$ Forestry and Wildlife Science Research Institute (FWRSI), Forestry Administration (Norodom \\ Boulevard, Phnom Penh, Cambodia)
}

\begin{abstract}
Forest soils in the basalt region of Southeast Asia are important natural resources, due to their high agricultural potential and high capacity for carbon sequestration. To characterize the physicochemical properties and the components of the soil organic carbon of forest soils in the basalt region, five evergreen sites (E1-5) and one deciduous forest site (D1) were selected in Cambodia at elevations ranging from 132 to $908 \mathrm{~m}$. The components of the soil organic carbon of each site were separated using a density fractionation approach, i.e. high- $\left(\geq 1.6 \mathrm{~g} \mathrm{~cm}^{-3}\right)$ and low- $\left(<1.6 \mathrm{~g} \mathrm{~cm}^{-3}\right)$ density fractions. Soils of sites E1 and E2, at high elevation $(>600 \mathrm{~m})$, were strongly weathered and characterized by a lower $\mathrm{pH}$, a lower level of exchangeable bases, and a more reddish color than the other evergreen forest soils. The soils of sites E3 and E4, located on a hillside and at the base of a hill, respectively, had a high soil effective cation exchange capacity in the B horizons compared to those at sites E1-2 and E5. The soil of site E5 in the isolated basalt region had characteristics resembling those in sites E1-2 except for its high exchangeable aluminum content. The site D1 soil on a hillside was relatively young and shallow, and black in color. The carbon stock in the six forest sites $(0-30 \mathrm{~cm}$ in depth) was $40.8-$ 113.7 $\mathrm{Mg} \mathrm{C} \mathrm{ha}^{-1}$ for high-density fractions and 3.3-7.6 $\mathrm{Mg} \mathrm{C} \mathrm{ha}^{-1}$ for low-density fractions, respectively. The differences in vegetation types (deciduous vs. evergreen forests), mean annual temperature and free aluminum contents among forest sites were considered factors affecting the carbon content and carbon to nitrogen $(\mathrm{C} / \mathrm{N})$ ratio of high-density fractions. It was considered that the variously weathered parent materials, regulated by the relative position in the basalt plateau, were responsible for the gradient of soil morphology and soil nutrient conditions and characterized the soil carbon stock in the study area.
\end{abstract}

Discipline: Forestry and forest products

Additional key words: tropical monsoon forest

\section{Introduction}

Over a large area of Southeast (SE) Asia, red-colored soils sustain the primary production of tropical forests. These red-colored soils can be broadly divided into two types: Acrisols widely distributed across SE Asia and Ferralsols with localized distribution ${ }^{5}$. The two soil types differ, particularly in terms of their physical properties. Acrisols are more susceptible to erosion than Fer-

ralsols and carry a high risk of subsoil exposure, raising the soil aluminum concentration to a toxic level, following the mechanical clearing of natural forest ${ }^{5}$. Meanwhile, Ferralsols have a lower risk of erosion than Acrisols and a high potential for agricultural production after forest logging ${ }^{2,5,7}$. Therefore the distribution and physicochemical characteristics of Ferralsols are of particular interest in SE Asian countries ${ }^{6}$.

The broad distribution of Ferralsols and their associated soil types (formerly known as Latosols) in SE Asia is

* Corresponding author: e-mail jtori@affrc.go.jp

Received 29 May 2012; accepted 19 September 2012. 
restricted to areas on easily weathered basic rock, typically basalt ${ }^{5,6}$. Ferralsols, and their associated soil types of basic rock origin, occur under wide-ranging climates where the mean annual temperature exceeds $22^{\circ} \mathrm{C}$ and the mean annual precipitation exceeds $700 \mathrm{~mm}^{6}$. They are distributed in parts of Cambodia, Vietnam, Thailand, Malaysia, and Indonesia ${ }^{6}$. Tropical monsoon forests still remain in eastern and northeastern parts of Cambodia, where Neogene to Quaternary basalt is distributed ${ }^{22,23}$. However, the physicochemical properties of the region's forest soils are still not fully understood, despite increasing pressures from rapid economic growth and development.

Earlier studies of Cambodian basalt soils focused on agricultural production and soil mapping ${ }^{2,7,9}$ and clarified that "red soil" or Latosols (= Ferralsols) occurred on basalt area in combination with "black or brown soils" or basic Lithosols?. The red soil was recognized as having high agricultural potential for rubber plantations, compared to the neighboring black or brown soils ${ }^{2,7,9}$. Recently, studies have also examined carbon sequestration in basalt soil in relation to reducing atmospheric greenhouse gas levels and thus minimizing the effects of global warming. Toriyama et al. ${ }^{16}$ reported that forest soils on basalt had a higher mean carbon stock than those on sedimentary rocks for both evergreen and deciduous forest types in Cambodia. The composition of soil organic carbon, however, remains uncertain.

Soil organic carbon consists of various functional pools with different chemical properties and turnover rates $^{11,12,20,21}$. The density fractionation approach is intended to separate these functional pools by the use of heavy liquid $^{12,20}$. In many cases, the low-density fractions such as fresh plant debris have high carbon to nitrogen $(\mathrm{C} / \mathrm{N})$ ratios and turnover rates, compared to high-density fractions such as organo-mineral complex ${ }^{11,12,20,21}$. The climatic and mineral controls governing the quality and turnover rates of each density fraction are important processes for the stabilization of soil organic carbon ${ }^{12,21}$. These studies have also helped develop the conceptual models that explain the flow of soil organic carbon in the decomposition process ${ }^{12,20}$. By evaluating the density fractions of soil organic carbon in tropical monsoon forests where the functional pools of soil carbon are less well studied, future study could upgrade the conceptual models to the process models for predicting carbon dioxide emissions from forest soils during forest logging and sequential agricultural production in the region. As a preliminary study, the density fractionation of soil carbon should be applied to several forest sites, including different forest types and topographic features in tropical monsoon regions. Accordingly, this study aimed to characterize the soil physicochemical properties and the components of soil organic carbon using the density fractionation approach and clarifying their relationships to the basaltic landscape in tropical monsoon forests on Cambodian basalt.

\section{Materials and methods}

\section{Study site}

The study site was located in Mondulkiri and Kampong Thom provinces, Cambodia (Fig. 1). The geology of the two regions is extensively basalt and referred to as Neogene to Quaternary mafic volcanic rocks ${ }^{22,23}$. In both regions, five evergreen sites (E1-5) and a deciduous forest site (D1) were selected.

The study area in Mondulkiri is an undulating zone near the border with Vietnam (Fig. 1). The study area forms part of a basalt plateau with a height below $1000 \mathrm{~m}$ a.s.l. The mean annual temperature and rainfall of Mondulkiri province (around $900 \mathrm{~m}$ a.s.1.) are $20^{\circ} \mathrm{C}$ and 2250 $\mathrm{mm}$, respectively. A hill evergreen forest plot (E1) at 908 $\mathrm{m}$ a.s.l., three secondary evergreen forest plots (E2-4) at 687,461 , and $227 \mathrm{~m}$, respectively, and a deciduous dipterocarp forest plot (D1) at $526 \mathrm{~m}$ were established. In the high elevation area of Mondulkiri, shifting cultivation has been conducted by ethnic groups, similarly to the other mountainous areas of Cambodia ${ }^{2}$. The repeated burning of grassland has also been conducted in the area surrounding the E1 site ${ }^{2}$. However, little information ex-

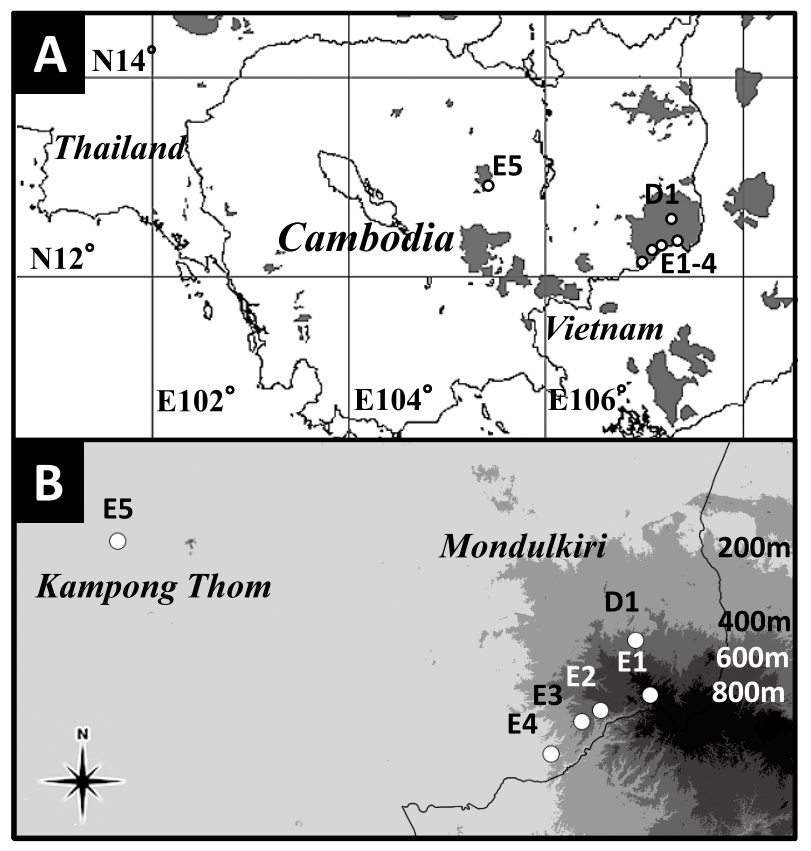

Fig. 1. Location of the study site

The gray area in map A shows the distribution of basalt ${ }^{22}$. The numbers in map B denote the elevation at $200-\mathrm{m}$ intervals. 
ists on the land use history of each forest site. The study area in Kampong Thom is in the flat part of central Cambodia, $200 \mathrm{~km}$ west of Mondulkiri, and a type of isolated basalt region that is widely found in central Cambodia. The mean annual temperature and rainfall of Kampong Thom province are $27^{\circ} \mathrm{C}$ and $1800 \mathrm{~mm}$, respectively. A secondary evergreen forest plot (E5) at $132 \mathrm{~m}$ a.s.l. was established in this region. Field surveys were conducted in May 2004 (Mondulkiri) and February 2006 (Kampong Thom). The forest biomass was highest in the secondary evergreen forest (sites E2-5), followed by the hill evergreen forest site (E1) and deciduous dipterocarp forest site (D1, Table 1).

\section{Soil morphology}

Sites E1-2 and site D1 are located in areas of Ferralsols and Cambisols, respectively, and sites E3-4 are on the transitional zone between the two soil types ${ }^{2}$. Site E5 is situated in an area of Acrisols ${ }^{2}$. In each forest plot, soil auger boring was undertaken to obtain a representative soil profile in the area and we established soil profiles ranging from 90 to $200 \mathrm{~cm}$ in thickness (Appendix 1). In general, the high elevation $(>600 \mathrm{~m}$ ) evergreen forest soils exhibited more advanced weathering of soil parent materials compared to those at low elevation $(<500 \mathrm{~m})$ sites, except for the E5 site. The main soil color was redder in sites E1 and E5 (2.5YR in Munsell color), followed by sites E2, E3, and D1 (5YR), and E4 (7.5YR) respectively. The soil of site Dl was black in color (5YR 1.7/12/1) in the A horizon. Soils in sites E1, E2, and E5 did not contain coarse mineral fractions. Weathered gravel or boulders were observed in sites E3, E4, and D1. The soil thickness exceeded $7 \mathrm{~m}$ in sites E1 and E2 and $1.5 \mathrm{~m}$ in site D1, according to a penetration test using a dynamic cone penetrometer ${ }^{8}$.

\section{Soil sampling and analysis}

Soil samples for physicochemical analysis were col- lected from each horizon and placed in plastic bags. Further soil samples to measure the bulk density, gravel, and coarse organic matter content were collected from the middle depth of each horizon and placed in three $100-\mathrm{mL}$ $\left(19.6 \mathrm{~cm}^{2} \times 5.1 \mathrm{~cm}\right)$ steel cylinders.

For air-dried soil samples $(<2 \mathrm{~mm}), \mathrm{pH}\left(\mathrm{H}_{2} \mathrm{O}\right.$ and $\mathrm{KCI})$ was determined using a glass electrode. The cation exchange capacity (CEC) and exchangeable bases (Ca, $\mathrm{Mg}, \mathrm{K}$, and $\mathrm{Na}$ ) were determined using ammonium acetate $^{13}(\mathrm{pH} 7)$ and atomic absorption and flame emission spectrometry (SOLAAR S2, Thermo Electron Co., Ltd.). Exchangeable $\mathrm{Al}$ and $\mathrm{H}$ were evaluated by titration using $1 \mathrm{M} \mathrm{KCl}^{25}$. The effective cation exchange capacity (ECEC) was defined as the sum of exchangeable bases and exchangeable $\mathrm{Al}$ and $\mathrm{H}$. Base saturation and $\mathrm{Al}$ saturation were defined as the ratio of exchangeable bases to $\mathrm{CEC}$ and exchangeable $\mathrm{Al}$ to the ECEC, respectively. The total soil carbon (C) and nitrogen (N) contents were assessed using the dry combustion method (Sumigraph NC analyzer NC-22F,Sumika Chemical Analysis Service, Ltd.). Clay $(<0.002 \mathrm{~mm})$ and fine silt $(0.002-002 \mathrm{~mm})$ contents were determined using the pipette method $^{3}$, coarse silt $(0.02-0.063 \mathrm{~mm})$ and sand content $(0.063-2$ $\mathrm{mm}$ ) were measured using wet sieving, and particle density was analyzed using a pycnometer. The bulk density of fine soils $(<2 \mathrm{~mm})$ and the gravel and coarse organic matter $(\geq 2 \mathrm{~mm})$ content were measured on an oven-dry $\left(105^{\circ} \mathrm{C}, 24 \mathrm{~h}\right)$ basis. To evaluate mineral control on soil C storage, free $\mathrm{Fe}$ and $\mathrm{Al}$ contents ${ }^{1}$ were determined using acid ammonium oxalate $\left(\mathrm{Fe}_{\mathrm{o}}\right.$ and $\left.\mathrm{Al}_{\mathrm{o}}\right)$ and sodium-pyrophosphate extractions $\left(\mathrm{Fe}_{\mathrm{p}}\right.$ and $\mathrm{Al}_{\mathrm{p}}$ ), and inductively coupled plasma emission spectrometry (OPTIMA 4300 DV, PerkinElmer Co., Ltd.) for the same soil horizons as used for density fractionation.

\section{Density fractionation}

Density fractionation was conducted using soil samples from the upper three soil horizons $(<62 \mathrm{~cm}$ depth) of

Table 1. Vegetation and site condition of the study sites

\begin{tabular}{|c|c|c|c|c|c|c|}
\hline \multirow[t]{2}{*}{ Plot ID } & \multirow{2}{*}{$\frac{\text { Elevation }}{\mathrm{m}}$} & \multirow{2}{*}{$\begin{array}{c}\text { Slope } \\
\text { degree }\left(^{\circ}\right)\end{array}$} & \multirow{2}{*}{$\frac{\text { Basal area }}{\mathrm{m}^{2} \mathrm{ha}^{-1}}$} & \multirow{2}{*}{$\frac{\mathrm{AGB}^{* 1}}{\mathrm{Mg} \mathrm{ha}^{-1}}$} & \multirow[t]{2}{*}{ Forest type } & \multirow[t]{2}{*}{ Major tree species } \\
\hline & & & & & & \\
\hline E1 & 908 & 13 & 29.1 & 197 & $\mathrm{HEF}^{* 2}$ & Schima wallichii, Lithocarpus sp. \\
\hline $\mathrm{E} 2$ & 697 & 3 & 37.8 & 278 & $\mathrm{SEF}^{* 3}$ & Dipterocarpus costatus, Girroniera sp. \\
\hline E3 & 427 & 12 & 28.1 & 183 & SEF & Peltophorum dasyrrhachis \\
\hline $\mathrm{E} 4$ & 229 & 12 & 46.3 & 374 & SEF & Irvingia malayana \\
\hline E5 & 132 & 2 & 29.2 & 218 & SEF & I. malayana, P. dasyrrhachis \\
\hline D1 & 501 & 7 & 21.4 & 116 & $\mathrm{DDF}^{* 4}$ & Shorea siamensis \\
\hline
\end{tabular}

${ }^{* 1} \mathrm{AGB}=$ aboveground biomass; ${ }^{* 2} \mathrm{HEF}=$ hill evergreen forest $;{ }^{* 3} \mathrm{SEF}=$ secondary evergreen forest $;{ }^{* 4} \mathrm{DDF}=$ deciduous dipterocarp forest. Forest data are based on those of Tani et al. ${ }^{14}$ 
each plot, following the procedure of previous studies ${ }^{4,21}$ with a minor change. We separated bulk soil samples into four density fractions. Air-dried soil samples (10 g) were mixed with $1.6 \mathrm{~g} \mathrm{~cm}^{-3}$ sodium polytungstate (SPT; 30 $\mathrm{mL}$ ) solution and centrifuged (2000 g, $30 \mathrm{~min})$. The floating material in the SPT solution was then rinsed with deionized water on a glass fiber filter (Kiriyama GF-P, Kiriyama Glass Co., Ltd.) until the electrical conductivity of rinse water became $<50 \mu \mathrm{S} \mathrm{cm}^{-1}$. This material was collected as a free low-density fraction (fLF) and then oven-dried at $60^{\circ} \mathrm{C}$. The sediment in the SPT solution was treated with ultrasound $\left(80 \mathrm{~W}, 5 \mathrm{~min}, 711 \mathrm{~J} \mathrm{~mL}^{-1}\right)$ in a 50 $\mathrm{mL}$ tube in ice water using a sonicator with a $13-\mathrm{mm}$ diameter tip. The floating material after sonication (occluded low-density fraction, oLF) was recovered using the same procedure as the fLF recovery. The remaining sediment after sonication was separated by wet-sieving (63 $\mu \mathrm{m})$. The coarse high-density fraction (cHF, $\geq 63 \mu \mathrm{m}$ ) was oven-dried at $60^{\circ} \mathrm{C}$ and the fine high-density fraction (fHF, $<63 \mu \mathrm{m}$ ) was freeze-dried. The $\mathrm{C}$ and $\mathrm{N}$ contents of the four density fractions were analyzed in the same way as the bulk soil samples. In this study, the fLF contained some clay minerals, which clung to plant debris (Appendix 2). To estimate the C content of the fLF in topsoil, excluding clay minerals, we measured the weight of the fLF in topsoil before and after the dry combustion in the $\mathrm{C}$ content measurement. The total $\mathrm{C}$ stock at a depth of 0-30 cm was calculated for the low- and high-density fractions, respectively.

\section{Results}

\section{Soil physicochemical properties}

In general, soil chemical properties were clearly distinguishable between deciduous (site D1) and evergreen forest soils (sites E1-5), and the soils of sites E1-2 also differed in certain chemical properties from those of sites E3-5. The soil of site D1 had higher $\mathrm{pH}\left(\mathrm{H}_{2} \mathrm{O}\right)$, exchangeable bases, ECEC, and base saturation than those of the evergreen forests (Table 2). The soil exchangeable base levels for site D1 were particularly high in calcium and magnesium compared to those of the evergreen forest soils. The soil of sites E1-2 had a higher $\mathrm{pH}(\mathrm{KCl})$ and lower Al saturation in the B horizons than the soils of sites E3-5 (Table 2). The ECEC in the B horizons was lowest in sites E1-2 $\left(0.2-0.8 \mathrm{cmol} \mathrm{kg}^{-1}\right)$, followed by sites E5 (1.0-1.2) and E3-4 (5.4-8.6).

The soil carbon to nitrogen ratio $(\mathrm{C} / \mathrm{N}$ ratio) and soil physical properties were related to elevation. The soil $\mathrm{C} / \mathrm{N}$ ratios of evergreen forests increased with elevation, except for the $\mathrm{E} 4$ site (Table 3 ). The soil $\mathrm{C} / \mathrm{N}$ ratios in the E1-2 sites were lower in the topsoil than the subsoil, un- like those of the soils at sites E3-5 and D1. The soils of sites E1-2 had lower clay content in the B horizons those in sites E3-5. The mean soil particle density in the B horizons was low $\left(2.64 \mathrm{~g} \mathrm{~cm}^{-3}\right)$ at site $\mathrm{E} 4$ and high $(3.03 \mathrm{~g}$ $\mathrm{cm}^{-3}$ ) at site E1 (Table 3). The gravel content was clearly higher in the soils of sites E3-4 and D1. No clear trend in coarse organic matter content was observed except for a high value in the soil at site E2.

\section{Density fractionation and free $\mathrm{Fe}$ and $\mathrm{Al}$ contents}

In this section, we refer to the total $\mathrm{C}$ (or $\mathrm{N}$ ) of four density fractions as "four pool-C (or four pool-N)" and distinguish it from the "total soil C (or total soil N)" of bulk soil. The mean recovery of soil mass (= total mass of the four density fractions) was $98.8 \%$ for bulk soil samples $(N=18$; Fig. 2a). The mean recoveries of four pool-C and $-\mathrm{N}$ were 92.2 and $98.4 \%$ for total soil $\mathrm{C}$ and $\mathrm{N}$, respectively $(N=18$; Fig. $2 \mathrm{~b}, 2 \mathrm{c})$. In the topsoil horizons (< $11 \mathrm{~cm}$ depth; $N=6$; Figs. 2b, 2c), the LF (fLF + oLF) accounted for 10.3 and $6.2 \%$ of total soil $\mathrm{C}$ and $\mathrm{N}$, respectively. The mass of the LF in the second and third soil horizons ( $\geq 11 \mathrm{~cm}$ depth) was so low and undetectable, and the LF-C and -N accounted for 2.8 and $1.3 \%$ of total soil $\mathrm{C}$ and $\mathrm{N}$, respectively, in the third soil horizons (23-62 cm depth).

The $\mathrm{C}$ content in the four density fractions of topsoil was in the order of oLF $>\mathrm{fLF}>\mathrm{cHF}$, fHF (Fig. 3a). It was estimated that the fLF in topsoil contained $286 \pm 76 \mathrm{~g}$ $\mathrm{kg}^{-1}$ of clay minerals by weight and the $\mathrm{C}$ content of the fLF, excluding clay minerals, was $388 \pm 76 \mathrm{~g} \mathrm{~kg}^{-1}$. A change in the $\mathrm{C}$ content of the four density fractions with elevation was unclear, with the exception of the fHF, which correlated positively with elevation $\left(R^{2}=0.66\right.$ for topsoil; Fig. 3a). The $\mathrm{C} / \mathrm{N}$ ratios of the oLF, fLF, and $\mathrm{fHF}$ in topsoil peaked in the soil at site D1 (526 m elevation in Fig. $3 b$ ). The $\mathrm{C} / \mathrm{N}$ ratio of the $\mathrm{fHF}$ varied with elevation in the same manner as for bulk soil (Fig. 3b) because the fHF was the largest component of bulk soil-C and -N. The $\mathrm{C}$ stock in the six forest sites $(0-30 \mathrm{~cm}$ depth) was 40.8-113.7 $\mathrm{Mg} \mathrm{C} \mathrm{ha}^{-1}$ for the HF (cHF + fHF) and 3.3-7.6 $\mathrm{Mg} \mathrm{C} \mathrm{ha-1} \mathrm{for} \mathrm{the} \mathrm{LF} \mathrm{(fLF} \mathrm{+} \mathrm{oLF),} \mathrm{respectively} \mathrm{(Fig.} \mathrm{4).}$ The $\mathrm{Al}_{\mathrm{o}}, \mathrm{Al}_{\mathrm{p}}$, and $\mathrm{Fe}_{\mathrm{p}}$ contents were high in the soils of sites E1-2. The $\mathrm{Fe}_{\mathrm{o}}$ content was higher in the soil of sites E4 and D1 than elsewhere (Table 4).

\section{Discussion}

\section{Characteristics of red- and black-colored soils in relation to the basaltic landscape}

The physicochemical properties of red- and blackcolored soils might be influenced by their relative position on the basalt plateau ${ }^{2,7,10}$. On basalt plateaus in cen- 
tral Cambodia, where the elevation is below $200 \mathrm{~m}$, red soils typically occur on the internal side of the basalt plateau, whereas black or brown soils are more common at the outer edge ${ }^{2,7}$. In the red soil series in Mondulkiri (sites E1-4), the E1-2 sites were located on relatively flat table- land at high elevation ( $>600 \mathrm{~m}$ ), whereas the E3 and E4 sites were located on a hillside and the base of a hill, respectively. The soils of sites E1-2 were strongly weathered in terms of the lack of gravels and characterized by lower $\mathrm{pH}$ and exchangeable bases with a stronger red col-

Table 2. Soil chemical properties of the study sites

\begin{tabular}{|c|c|c|c|c|c|c|c|c|c|c|c|c|c|c|}
\hline \multirow{2}{*}{$\begin{array}{l}\text { Plot ID } \\
\text { (Elevation) }\end{array}$} & \multirow{2}{*}{ Horizon } & \multirow{2}{*}{\multicolumn{2}{|c|}{$\frac{\text { Depth }}{\mathrm{cm}}$}} & \multirow[t]{2}{*}{$\mathrm{pH}(\mathrm{KCl})$} & \multicolumn{2}{|c|}{$\mathrm{Ex}^{* 1} \mathrm{Ca} \mathrm{Ex} \mathrm{Mg}$} & Ex K & \multicolumn{2}{|c|}{ Ex Na Ex Al } & \multirow[t]{2}{*}{ Ex H } & \multirow[t]{2}{*}{ ECEC } & \multirow[t]{2}{*}{$\mathrm{CEC}$} & \multicolumn{2}{|c|}{ Base sat.*2 Al sat.*2 } \\
\hline & & & & & & & & $\mathrm{cmol}$ & $\mathrm{kg}^{-1}$ & & & & $\%$ & \\
\hline \multirow{8}{*}{$\begin{array}{l}\text { E1 } \\
(908 \mathrm{~m})\end{array}$} & Ah1 & 8 & 4.53 & 4.02 & 0.09 & 0.36 & 0.29 & 0.12 & 1.98 & 1.21 & 4.0 & 24.7 & 3.4 & 8.0 \\
\hline & Ah2 & 25 & 4.64 & 4.39 & 0.01 & 0.07 & 0.11 & 0.04 & 0.33 & 0.94 & 1.5 & 17.7 & 1.3 & 1.9 \\
\hline & B1 & 53 & 5.03 & 5.75 & 0.02 & 0.02 & 0.05 & 0.03 & 0.00 & 0.20 & 0.3 & 9.5 & 1.2 & 0.0 \\
\hline & B2 & 82 & 4.94 & 5.30 & 0.01 & 0.00 & 0.03 & 0.03 & 0.00 & 0.16 & 0.2 & 8.0 & 0.9 & 0.0 \\
\hline & B3 & 126 & 5.04 & 5.82 & 0.01 & 0.00 & 0.03 & 0.02 & 0.00 & 0.20 & 0.3 & 6.1 & 1.0 & 0.0 \\
\hline & B4 & 149 & 5.09 & 5.92 & 0.01 & 0.00 & 0.03 & 0.02 & 0.00 & 0.20 & 0.3 & 7.6 & 0.9 & 0.0 \\
\hline & B5 & 185 & 5.06 & 6.07 & 0.01 & 0.00 & 0.03 & 0.03 & 0.00 & 0.26 & 0.3 & 4.9 & 1.4 & 0.0 \\
\hline & $\mathrm{BC}$ & 200 & 5.05 & 6.09 & 0.01 & 0.00 & 0.03 & 0.02 & 0.00 & 0.13 & 0.2 & 8.9 & 0.7 & 0.0 \\
\hline \multirow{7}{*}{$\begin{array}{l}\text { E2 } \\
(697 \mathrm{~m})\end{array}$} & Ah1 & 10 & 4.39 & 4.22 & 0.51 & 0.44 & 0.22 & 0.04 & 0.94 & 0.96 & 3.1 & 15.9 & 7.5 & 5.9 \\
\hline & Ah2 & 35 & 4.91 & 4.60 & 0.05 & 0.11 & 0.12 & 0.04 & 0.00 & 0.38 & 0.7 & 14.9 & 2.2 & 0.0 \\
\hline & BA & 62 & 4.76 & 4.50 & 0.01 & 0.02 & 0.04 & 0.01 & 0.00 & 0.71 & 0.8 & 12.2 & 0.7 & 0.0 \\
\hline & B1 & 92 & 4.88 & 4.93 & 0.01 & 0.01 & 0.04 & 0.05 & 0.00 & 0.14 & 0.3 & 11.0 & 1.1 & 0.0 \\
\hline & B2 & 126 & 4.95 & 5.34 & 0.01 & 0.01 & 0.04 & 0.03 & 0.00 & 0.21 & 0.3 & 10.4 & 0.9 & 0.0 \\
\hline & B3 & 160 & 4.96 & 5.43 & 0.01 & 0.01 & 0.03 & 0.02 & 0.00 & 0.16 & 0.2 & 10.2 & 0.8 & 0.0 \\
\hline & B4 & 200 & 5.01 & 5.42 & 0.03 & 0.01 & 0.04 & 0.04 & 0.00 & 0.20 & 0.3 & 9.1 & 1.4 & 0.0 \\
\hline \multirow{7}{*}{$\begin{array}{l}\text { E3 } \\
(427 \mathrm{~m})\end{array}$} & Ah1 & 9 & 5.13 & 3.98 & 3.57 & 5.57 & 0.41 & 0.08 & 1.60 & 1.65 & 12.9 & 30.3 & 31.8 & 5.3 \\
\hline & Ah2 & 23 & 5.09 & 3.86 & 0.12 & 1.94 & 0.14 & 0.06 & 7.65 & 1.44 & 11.3 & 30.2 & 7.5 & 25.3 \\
\hline & BA & 52 & 5.03 & 3.95 & 0.04 & 0.59 & 0.07 & 0.05 & 6.33 & 1.53 & 8.6 & 40.6 & 1.9 & 15.6 \\
\hline & B1 & 82 & 4.94 & 3.97 & 0.04 & 0.29 & 0.06 & 0.03 & 5.28 & 1.45 & 7.1 & 40.2 & 1.0 & 13.1 \\
\hline & B2 & 111 & 4.93 & 4.03 & 0.02 & 0.17 & 0.05 & 0.02 & 4.21 & 1.27 & 5.7 & 34.1 & 0.8 & 12.4 \\
\hline & $\mathrm{BC}$ & 145 & 4.91 & 3.92 & 0.03 & 0.14 & 0.05 & 0.02 & 5.41 & 1.18 & 6.8 & 44.8 & 0.6 & 12.1 \\
\hline & $\mathrm{CB}$ & 200 & 4.94 & 3.87 & 0.10 & 0.28 & 0.06 & 0.07 & 6.09 & 1.39 & 8.0 & 32.7 & 1.5 & 18.6 \\
\hline \multirow{4}{*}{$\begin{array}{l}\mathrm{E} 4 \\
(229 \mathrm{~m})\end{array}$} & $\mathrm{Ah}$ & 7 & 4.86 & 3.91 & 0.61 & 1.53 & 0.46 & 0.09 & 1.14 & 1.39 & 5.2 & 14.1 & 19.0 & 8.0 \\
\hline & B1 & 24 & 4.66 & 3.69 & 0.06 & 0.58 & 0.20 & 0.03 & 3.72 & 1.26 & 5.8 & 13.9 & 6.2 & 26.8 \\
\hline & B2 & 43 & 4.85 & 3.81 & 0.03 & 0.45 & 0.15 & 0.04 & 3.46 & 1.40 & 5.5 & 16.0 & 4.2 & 21.6 \\
\hline & $\mathrm{RB}$ & 110 & 4.90 & 3.80 & 0.02 & 0.00 & 0.11 & 0.06 & 3.72 & 1.52 & 5.4 & 12.6 & 1.6 & 29.4 \\
\hline \multirow{6}{*}{$\begin{array}{l}\text { E5 } \\
(132 \mathrm{~m})\end{array}$} & $\mathrm{A} 1$ & 10 & 4.32 & 3.82 & 0.86 & 0.27 & 0.18 & 0.03 & 1.70 & 0.57 & 3.6 & 9.4 & 14.2 & 18.2 \\
\hline & $\mathrm{A} 2$ & 29 & 4.87 & 4.17 & 0.06 & 0.19 & 0.04 & 0.04 & 1.51 & 0.23 & 2.1 & 6.1 & 5.4 & 24.8 \\
\hline & B1 & 60 & 4.83 & 4.38 & 0.04 & 0.14 & 0.01 & 0.03 & 0.86 & 0.15 & 1.2 & 6.8 & 3.2 & 12.5 \\
\hline & B2 & 94 & 4.73 & 4.47 & 0.04 & 0.11 & 0.01 & 0.03 & 0.55 & 0.30 & 1.0 & 4.9 & 3.7 & 11.2 \\
\hline & B3 & 159 & 5.04 & 4.43 & 0.04 & 0.01 & 0.01 & 0.03 & 0.69 & 0.23 & 1.0 & 5.2 & 1.7 & 13.1 \\
\hline & B4 & 200 & 5.12 & 4.40 & 0.16 & 0.05 & 0.01 & 0.03 & 0.67 & 0.26 & 1.2 & 5.4 & 4.6 & 12.4 \\
\hline \multirow{5}{*}{$\begin{array}{l}\text { D1 } \\
(501 \mathrm{~m})\end{array}$} & $\mathrm{Ah}$ & 11 & 5.99 & 4.07 & 19.85 & 11.48 & 0.94 & 0.46 & 0.00 & 0.61 & 33.3 & 40.9 & 80.0 & 0.0 \\
\hline & Ahc & 26 & 5.82 & 3.78 & 15.25 & 10.96 & 0.64 & 0.19 & 0.48 & 1.13 & 28.7 & 38.7 & 69.9 & 1.3 \\
\hline & $\mathrm{Bc}$ & 39 & 6.30 & 4.00 & 18.25 & 12.42 & 0.62 & 0.28 & 0.00 & 0.74 & 32.3 & 36.6 & 86.3 & 0.0 \\
\hline & B & 71 & 7.05 & 4.26 & 25.22 & 17.79 & 0.40 & 0.43 & 0.00 & 0.40 & 44.2 & 40.7 & 107.7 & 0.0 \\
\hline & $\mathrm{CB}$ & 90 & 7.27 & 4.17 & 24.40 & 16.47 & 0.13 & 0.38 & 0.00 & 0.47 & 41.8 & 35.7 & 115.8 & 0.0 \\
\hline
\end{tabular}

\footnotetext{
${ }^{*} \mathrm{Ex}=$ exchangeable; ${ }^{* 2}$ Base and $\mathrm{Al}$ sat. $=$ base and $\mathrm{Al}$ saturation.
} 
or compared to the other evergreen forest soils. The high particle density in the B horizons of the soils of sites E1-2 indicated a high content of crystallized iron and alumi- num in the soil clay minerals. Compared to sites E1-2, the soils of sites E3-4 had high gravel and exchangeable base contents in the B horizons. The soil of site E5, in the

Table 3. Soil $\mathrm{C}$ and $\mathrm{N}$ contents and physical properties of the study sites

\begin{tabular}{|c|c|c|c|c|c|c|c|c|c|c|c|c|c|}
\hline \multirow{2}{*}{$\begin{array}{l}\text { Plot ID } \\
\text { (Elevation) }\end{array}$} & \multirow[t]{2}{*}{ Horizon } & Depth & $\mathrm{TC}^{* 1}$ & $\mathrm{TN}^{* 1}$ & \multirow[t]{2}{*}{$\mathrm{C} / \mathrm{N}$} & Sand & C. silt*2 & F. silt*2 & Clay & $\mathrm{PD}^{* 3}$ & $\mathrm{BD}^{* 3}$ & Gravel*4 & \multirow{2}{*}{$\frac{\mathrm{COM}^{* 5}}{\mathrm{mg} \mathrm{cm}^{-3}}$} \\
\hline & & $\mathrm{cm}$ & \multicolumn{2}{|c|}{$\mathrm{g} \mathrm{kg}^{-1}$} & & \multicolumn{4}{|c|}{$\mathrm{g} \mathrm{kg}^{-1}$} & \multicolumn{3}{|c|}{$\mathrm{g} \mathrm{cm}^{-3}$} & \\
\hline E1 & Ah1 & 8 & 80.9 & 4.87 & 16.6 & 180 & 166 & 479 & 176 & 2.52 & 0.72 & 0.00 & 2.77 \\
\hline \multirow[t]{7}{*}{$(908 \mathrm{~m})$} & Ah2 & 25 & 50.7 & 2.68 & 19.0 & 297 & 206 & 337 & 160 & 2.79 & 0.83 & 0.00 & 1.10 \\
\hline & $\mathrm{B} 1$ & 53 & 22.8 & 1.16 & 19.8 & 515 & 151 & 201 & 134 & 2.98 & 0.90 & 0.00 & 0.27 \\
\hline & B2 & 82 & 13.0 & 0.67 & 19.3 & 620 & 102 & 144 & 134 & 3.04 & 0.95 & 0.00 & 0.00 \\
\hline & B3 & 126 & 10.7 & 0.57 & 18.8 & 806 & 85 & 68 & 40 & 3.05 & 0.88 & 0.01 & 0.03 \\
\hline & B4 & 149 & 9.0 & 0.43 & 20.8 & 729 & 63 & 118 & 90 & 3.05 & 1.00 & 0.01 & 0.07 \\
\hline & B5 & 185 & 7.2 & 0.39 & 18.5 & 788 & 125 & 62 & 25 & 3.05 & 0.97 & 0.01 & 0.00 \\
\hline & $\mathrm{BC}$ & 200 & 6.5 & 0.28 & 22.9 & 680 & 127 & 92 & 101 & 3.02 & 1.02 & 0.01 & 0.03 \\
\hline \multirow{7}{*}{$\begin{array}{l}\text { E2 } \\
(697 \mathrm{~m})\end{array}$} & Ah1 & 10 & 36.0 & 2.45 & 14.7 & 99 & 127 & 281 & 493 & 2.88 & 0.65 & 0.00 & 9.13 \\
\hline & Ah2 & 35 & 20.7 & 1.21 & 17.1 & 285 & 188 & 225 & 302 & 2.92 & 0.70 & 0.00 & 8.60 \\
\hline & BA & 62 & 19.5 & 1.05 & 18.6 & 206 & 216 & 315 & 263 & 2.92 & 0.80 & 0.00 & 6.10 \\
\hline & $\mathrm{B} 1$ & 92 & 11.6 & 0.65 & 17.8 & 310 & 286 & 203 & 201 & 2.91 & 0.83 & 0.01 & 0.03 \\
\hline & B2 & 126 & 7.5 & 0.50 & 15.0 & 303 & 133 & 211 & 353 & 2.95 & 0.92 & 0.01 & 0.00 \\
\hline & B3 & 160 & 5.4 & 0.36 & 15.2 & 456 & 169 & 187 & 189 & 2.94 & 0.95 & 0.02 & 0.03 \\
\hline & B4 & 200 & 5.4 & 0.37 & 14.5 & 195 & 133 & 255 & 418 & 2.91 & 0.95 & 0.02 & 0.07 \\
\hline \multirow{7}{*}{$\begin{array}{l}\text { E3 } \\
(427 \mathrm{~m})\end{array}$} & Ah1 & 9 & 58.7 & 4.16 & 14.1 & 96 & 79 & 89 & 736 & 2.62 & 0.73 & 0.14 & 6.39 \\
\hline & Ah2 & 23 & 22.6 & 1.84 & 12.3 & 49 & 2 & 85 & 865 & 2.75 & 0.63 & 0.38 & 1.71 \\
\hline & BA & 52 & 11.5 & 1.06 & 10.9 & 135 & 20 & 93 & 752 & 2.78 & 0.56 & 0.81 & 0.05 \\
\hline & $\mathrm{B} 1$ & 82 & 7.5 & 0.76 & 9.9 & 167 & 64 & 146 & 622 & 2.83 & 0.72 & 0.67 & 0.03 \\
\hline & B2 & 111 & 3.5 & 0.44 & 8.1 & 218 & 97 & 171 & 513 & 2.88 & 0.79 & 0.35 & 0.27 \\
\hline & $\mathrm{BC}$ & 145 & 4.0 & 0.47 & 8.5 & 219 & 96 & 142 & 543 & 2.83 & 1.13 & 0.06 & 0.30 \\
\hline & $\mathrm{CB}$ & 200 & 5.4 & 0.55 & 9.8 & 235 & 93 & 166 & 505 & 2.76 & 1.08 & 0.10 & 0.03 \\
\hline \multirow{4}{*}{$\begin{array}{l}\text { E4 } \\
(229 \mathrm{~m})\end{array}$} & $\mathrm{Ah}$ & 7 & 26.6 & 2.71 & 9.8 & 139 & 137 & 304 & 420 & 2.49 & 1.06 & 0.02 & 0.35 \\
\hline & B1 & 24 & 13.4 & 1.77 & 7.6 & 51 & 76 & 291 & 582 & 2.59 & 1.13 & 0.01 & 3.95 \\
\hline & B2 & 43 & 13.0 & 1.69 & 7.7 & 103 & 44 & 285 & 568 & 2.66 & 0.61 & 0.78 & 0.58 \\
\hline & $\mathrm{RB}$ & 110 & 9.9 & 1.38 & 7.2 & 111 & 71 & 279 & 538 & 2.68 & 0.48 & 1.01 & 2.55 \\
\hline \multirow{6}{*}{$\begin{array}{l}\text { E5 } \\
(132 \mathrm{~m})\end{array}$} & A1 & 10 & 32.9 & 2.71 & 12.1 & 30 & 58 & 68 & 843 & 2.79 & 1.08 & 0.00 & 2.32 \\
\hline & $\mathrm{A} 2$ & 29 & 12.3 & 1.08 & 11.4 & 25 & 47 & 59 & 869 & 2.84 & 1.09 & 0.00 & 1.63 \\
\hline & B1 & 60 & 6.5 & 0.68 & 9.6 & 30 & 20 & 77 & 872 & 2.85 & 1.15 & 0.00 & 0.07 \\
\hline & B2 & 94 & 4.2 & 0.54 & 7.8 & 30 & 31 & 81 & 857 & 2.84 & - & - & - \\
\hline & B3 & 159 & 4.6 & 0.54 & 8.4 & 45 & 45 & 167 & 743 & 2.87 & 1.23 & 0.00 & 0.25 \\
\hline & B4 & 200 & 4.6 & 0.51 & 9.0 & 44 & 51 & 174 & 731 & 2.90 & 1.08 & 0.00 & 0.27 \\
\hline \multirow{5}{*}{$\begin{array}{l}\text { D1 } \\
(501 \mathrm{~m})\end{array}$} & $\mathrm{Ah}$ & 11 & 42.3 & 2.10 & 20.1 & 218 & 208 & 255 & 320 & 2.68 & 1.07 & 0.01 & 2.00 \\
\hline & Ahc & 26 & 25.1 & 1.46 & 17.2 & 416 & 136 & 199 & 248 & 2.76 & 0.89 & 0.45 & 0.13 \\
\hline & $\mathrm{Bc}$ & 39 & 11.1 & 0.79 & 14.1 & 502 & 103 & 135 & 261 & 2.75 & 0.79 & 0.67 & 0.07 \\
\hline & B & 71 & 5.3 & 0.50 & 10.7 & 401 & 87 & 175 & 337 & 2.71 & 1.31 & 0.18 & 0.23 \\
\hline & CB & 90 & 1.4 & 0.19 & 7.2 & 641 & 132 & 147 & 81 & 2.75 & 1.23 & 0.44 & 0.33 \\
\hline
\end{tabular}

${ }^{{ }^{*}} \mathrm{TC}$ and $\mathrm{TN}=$ total soil carbon and nitrogen contents; ${ }^{{ }^{*} 2} \mathrm{C}$. and $\mathrm{F}$. silt $=$ coarse and fine silt; ${ }^{* 3} \mathrm{PD}$ and $\mathrm{BD}=$ particle and bulk density; ${ }^{* 4}$ Gravel $=$ gravel content $(>2 \mathrm{~mm}) ;{ }^{* 5} \mathrm{COM}=$ coarse organic matter content $(>2 \mathrm{~mm})$. 
isolated basalt region, had closer characteristics to those of the soils of sites E1-2 except for its high exchangeable aluminum content. These differences indicated that the soils of sites E1-2 and E5 on the stable landform of the basalt plateau had been formed over a longer time than the soils of sites E3-4. In addition, the soil of site E4, on the outer edge of the basalt plateau, might be more resistant to weathering than the others because it contained abundant quartz sand, which was supported by the low
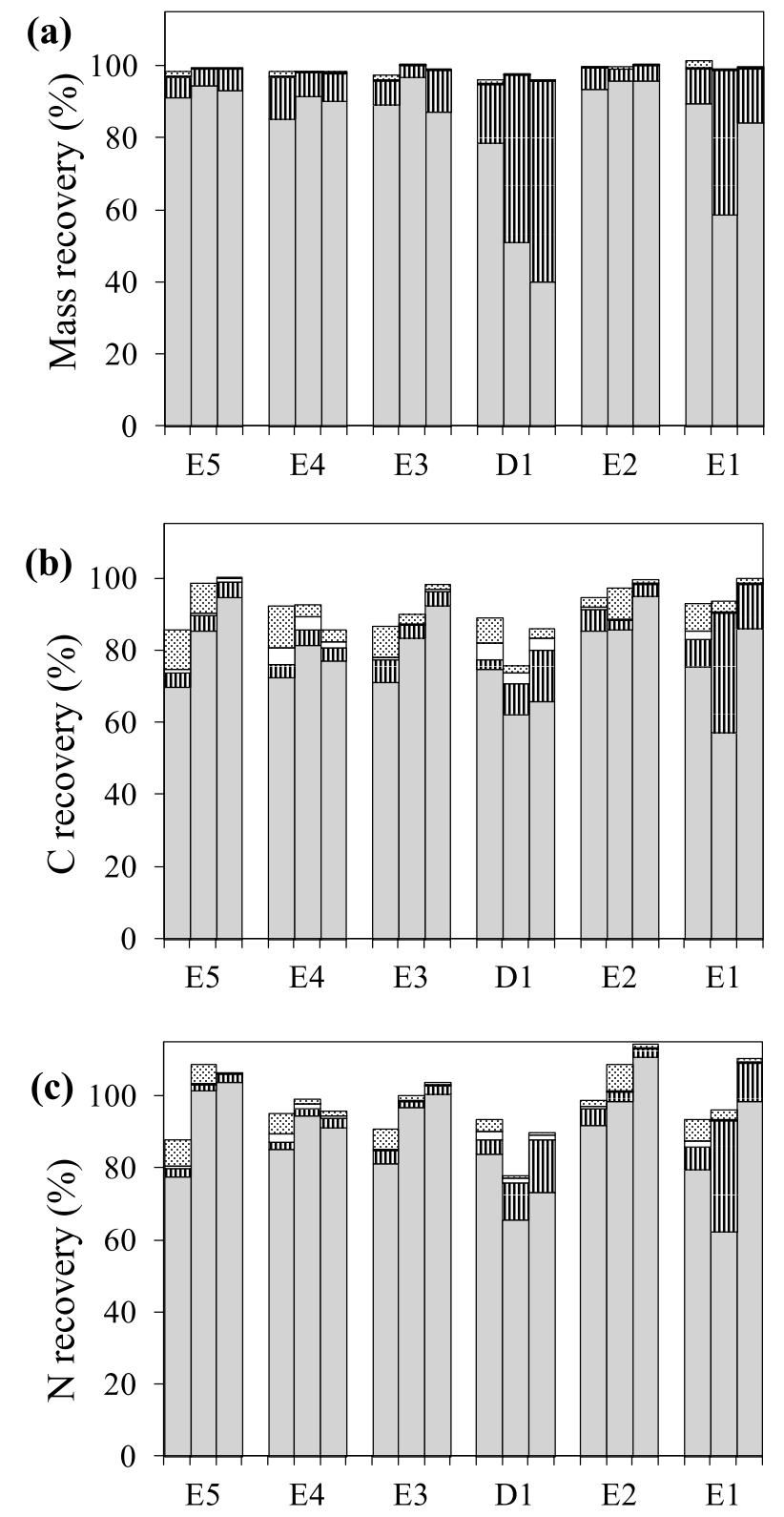

Fig. 2. Recovery of mass, carbon, and nitrogen in density fractionation

(a) Mass (b) Carbon (c) Nitrogen. The set of three bars in each plot shows the top (left), the second (middle), and the third (right) soil horizons respectively. The six plots are arranged in order of site elevation (left side is lower).

图: fLF, $\square$ : oLF, 血: cHF, $\square$ : fHF. particle density and a visual judgment of the sand fraction (Table 3).

The occurrence of black soils might also be related to the time of soil formation, as regulated by the position in the basaltic landscape. The soil of site D1 on a hillside was particularly young, compacted, and shallow, was similar to the "black soil" found in central Cambodia ${ }^{7}$. The presence of fresh rocks in the soil of site D1 might restrict the downward movement of exchangeable bas$\mathrm{es}^{7,15,17,19}$. The enriched exchangeable calcium and magnesium in the soil of site D1, as with limestone soils ${ }^{18}$, would increase the sorption of soil carbon onto clay minerals ${ }^{12}$ and help strengthen the black color of the soil organic matter.

The relationship between $\Delta \mathrm{pH}(=\mathrm{pH}(\mathrm{KCl})-$ $\left.\mathrm{pH}\left(\mathrm{H}_{2} \mathrm{O}\right)\right)$ and ECEC in B horizons could show the order of the weathering stage of six sites, from young D1 to advanced E1 (Fig. 5). The positive value of $\Delta \mathrm{pH}$ in sites E1-2 is a typical feature of Ferralsols, rich in sesquioxide (Fig. 5). In summary, it was considered that the variously weathered parent materials, regulated by the relative position in the basalt plateau, resulted in a gradient of soil morphology and soil nutrient conditions in the study area.

\section{Evaluation of soil carbon components and its implications}

In this study, the variation in soil $\mathrm{C}$ content was primarily attributable to the $\mathrm{C}$ content of the high-density fractions across the whole range of elevation. The sorption of soil carbon on clay minerals was considered the key process for stabilization of soil carbon in the study area. The formation of Al-humus complex also stabilizes soil organic matter by inhibiting microbial degradation ${ }^{12}$. The increase in $\mathrm{C}$ content in the fHF with elevation (Fig. 3a) might be explained by the gradient of free aluminum (Table 4). In addition, the effect of climatic conditions on the $\mathrm{C}$ content of $\mathrm{fHF}$ is worth considering. The variation in elevation from 132 (E5) to $908 \mathrm{~m}$ (E1) in the study area can mean a difference in mean annual temperature of $4.7^{\circ} \mathrm{C}$, assuming the change in air temperature as a function of elevation to be $0.6{ }^{\circ} \mathrm{C}$ per $100 \mathrm{~m}$. The cooler temperature at sites of higher elevation could result in slower decomposition on the surface of clay minerals. Unlike the HF-C, the contribution of the LF-C to total soil C in the topsoil was unrelated to elevation (Fig. 4), generally low (3.3-16.1\%), and comparable to previous measurements in humid tropical forests ${ }^{21}$ where the LF-C accounted for 5.6 (Oxisols) to $17.8 \%$ (Ultisols) of total soil C (0-10 cm in depth, located on the slope of Mt. Kinabalu at $700 \mathrm{~m}$ in elevation).

The trend in the soil $\mathrm{C} / \mathrm{N}$ value also matched that of the high-density fractions of fine particle sizes (Fig. 3b). 
(a)

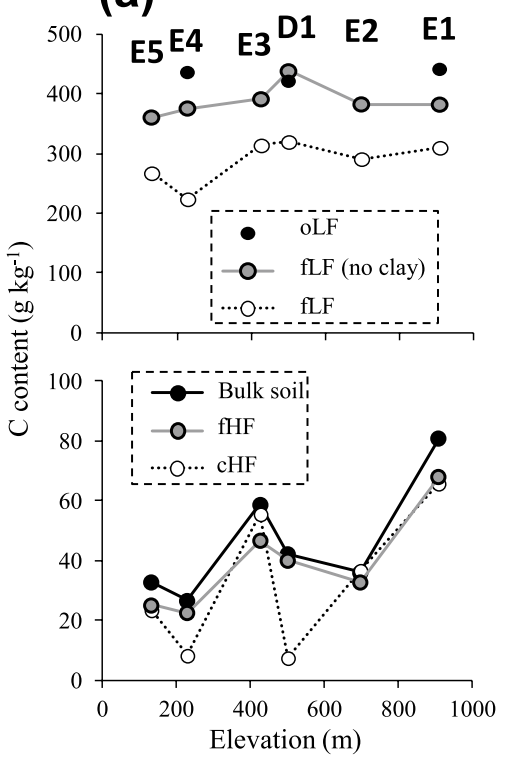

(b)

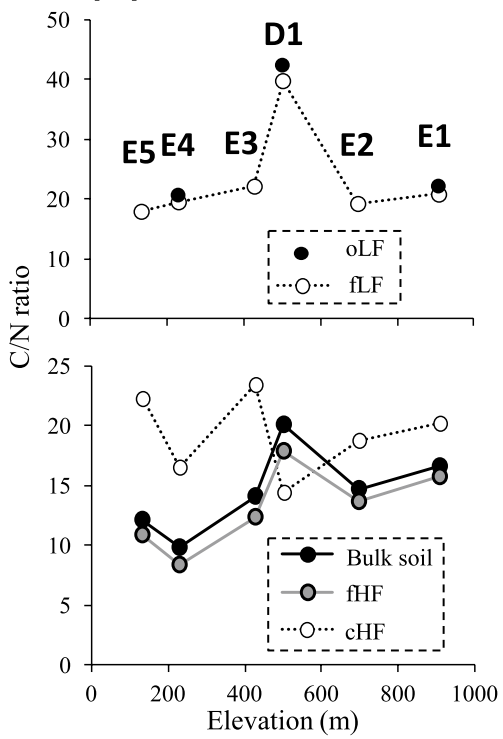

Fig. 3. Carbon content and $\mathrm{C} / \mathrm{N}$ ratio of density fractions in topsoil

(a) $\mathrm{C}$ content (b) $\mathrm{C} / \mathrm{N}$ ratio. Plot ID is displayed above the graphs. The fLF (no clay) represents fLF excluding clay minerals, which was estimated assuming that 1) plant debris contained $10 \%$ ash, 2) the weight of clay minerals was constant before and after the dry combustion, and 3) the $\mathrm{C}$ content of clay minerals was the same as that of the fHF. The oLF in part of the plots was not analyzed due to the small sample size.

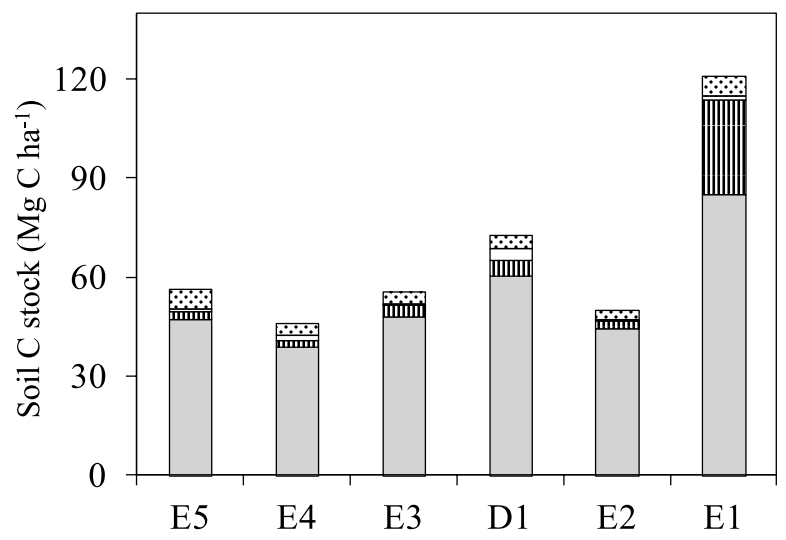

Fig. 4. Soil carbon stock at $0-30 \mathrm{~cm}$ depth

The six plots are arranged in order of site elevation (left side is lower).

图: fLF, $\square$ : oLF, 血 : cHF, $\square$ : fHF.

The higher $\mathrm{C} / \mathrm{N}$ ratio of $\mathrm{fHF}$ in site $\mathrm{D} 1$ than the other evergreen forest sites may reflect the high $\mathrm{C} / \mathrm{N}$ ratio of the supplied plant debris (LF) in the deciduous forest soil (Fig. 3b). Among five evergreen forest sites with similar $\mathrm{C} / \mathrm{N}$ ratios of $\mathrm{LF}$ (Fig. $3 \mathrm{~b}$ ), the higher $\mathrm{C} / \mathrm{N}$ ratios of $\mathrm{fHF}$ at sites E1-2 than those of E3-5 indicated the reduced microbial degradation of soil organic matter on clay minerals due to the higher free aluminum content and cooler temperature in E1-2 as discussed above. Another possible factor behind the high $\mathrm{C} / \mathrm{N}$ ratio of $\mathrm{fHF}$ in sites $\mathrm{E} 1-2$ was the land use history in the area of high elevation ${ }^{2}$, i.e. shifting cultivation by ethnic groups and repeated burn-
Table 4. Free oxide contents of the upper soil layers of the study sites

\begin{tabular}{|c|c|c|c|c|c|c|}
\hline \multirow{2}{*}{$\begin{array}{l}\text { Plot ID } \\
\text { (Elevation) }\end{array}$} & \multirow[t]{2}{*}{ Horizon } & Depth & ${ }^{* 1} \mathrm{Al}_{\mathrm{O}}$ & ${ }^{* 1} \mathrm{Fe}_{\mathrm{O}}$ & ${ }^{* 2} \mathrm{Al}_{\mathrm{p}}$ & \multirow[t]{2}{*}{${ }^{* 2} \mathrm{Fe}_{\mathrm{p}}$} \\
\hline & & $\mathrm{cm}$ & \multicolumn{3}{|c|}{$\mathrm{g} \mathrm{kg}^{-1}$} & \\
\hline E1 & Ah1 & 8 & 8.9 & 1.3 & 17.2 & 34.3 \\
\hline \multirow[t]{2}{*}{ (908 m) } & Ah2 & 25 & 9.0 & 1.0 & 12.5 & 23.5 \\
\hline & B1 & 53 & 8.2 & 1.2 & 5.3 & 11.8 \\
\hline E2 & Ah1 & 10 & 6.9 & 1.2 & 8.4 & 18.9 \\
\hline \multirow[t]{2}{*}{$(697 \mathrm{~m})$} & Ah2 & 35 & 5.5 & 1.3 & 2.0 & 3.8 \\
\hline & BA & 62 & 6.2 & 1.2 & 3.4 & 7.6 \\
\hline E3 & Ah1 & 9 & 5.7 & 1.8 & 5.2 & 8.4 \\
\hline \multirow[t]{2}{*}{$(427 \mathrm{~m})$} & Ah2 & 23 & 4.7 & 1.4 & 3.6 & 5.8 \\
\hline & $\mathrm{BA}$ & 52 & 3.9 & 1.2 & 2.0 & 1.6 \\
\hline E4 & $\mathrm{Ah}$ & 7 & 2.1 & 4.5 & 2.2 & 5.7 \\
\hline \multirow[t]{2}{*}{$(229 \mathrm{~m})$} & B1 & 24 & 1.6 & 4.1 & 2.2 & 6.3 \\
\hline & B2 & 43 & 1.7 & 3.5 & 2.2 & 6.2 \\
\hline E5 & $\mathrm{A} 1$ & 10 & 2.2 & 1.5 & 1.3 & 1.3 \\
\hline \multirow[t]{2}{*}{$(132 \mathrm{~m})$} & $\mathrm{A} 2$ & 29 & 2.3 & 1.5 & 0.6 & 0.1 \\
\hline & B1 & 60 & 2.2 & 1.6 & 0.4 & 0.0 \\
\hline D1 & $\mathrm{Ah}$ & 11 & 3.9 & 4.6 & 3.1 & 4.5 \\
\hline \multirow[t]{2}{*}{$(501 \mathrm{~m})$} & Ahc & 26 & 3.8 & 4.8 & 2.9 & 4.5 \\
\hline & $\mathrm{Bc}$ & 39 & 3.7 & 3.6 & 2.1 & 2.5 \\
\hline
\end{tabular}

*1 $\mathrm{Al}_{\mathrm{o}}, \mathrm{Fe}_{\mathrm{o}}=\mathrm{Al}$ and $\mathrm{Fe}$ extracted by acid ammonium oxalate; *2 $\mathrm{Al}_{\mathrm{p}}, \mathrm{Fe}_{\mathrm{p}}=\mathrm{Al}$ and $\mathrm{Fe}$ extracted by sodium-pyrophosphate 
ing of grassland, though little information on land use history was available for each forest plot. In the lowland

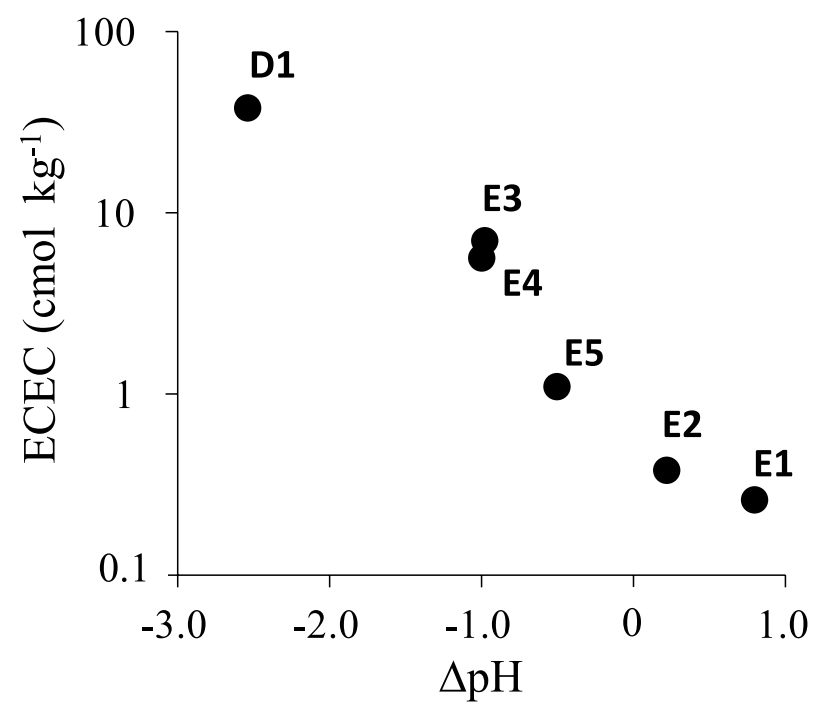

Fig. 5. Relationship between $\triangle \mathrm{pH}$ and ECEC in B horizons of forest soils in the study sites tropics ${ }^{24}$, the history of deforestation and the sequential occurrence of grassland increased soil $\mathrm{C} / \mathrm{N}$ ratios in subsoil horizons. Future studies used to analyze tree species composition or the use of stable isotope techniques could help clarify the effects of land use history on soil $\mathrm{C}$ stocks.

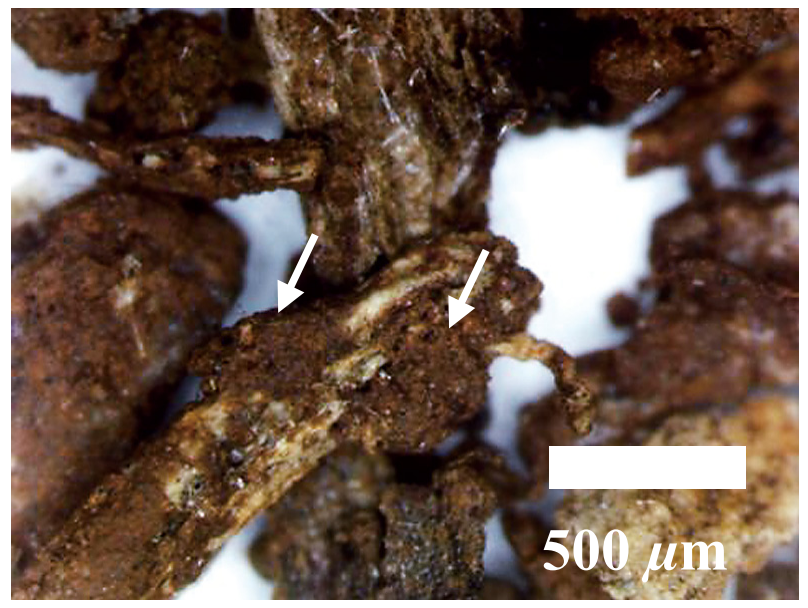

Appendix 2. Photograph of the free low-density fraction at site E1 (0-8 cm depth)

The arrows show how the clay clung to plant debris.

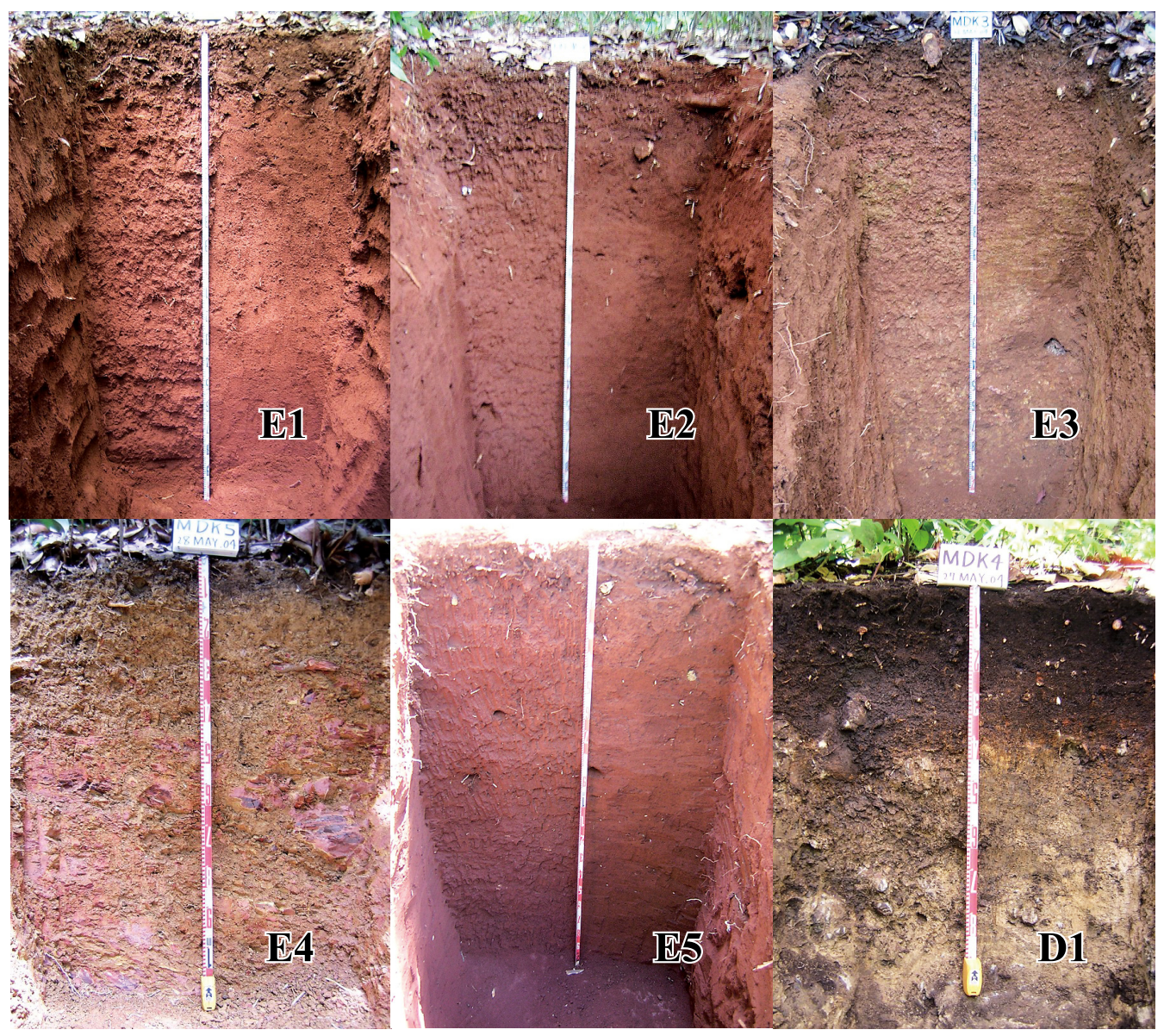

Appendix 1. Photographs of soil profiles 


\section{Acknowledgements}

This study was funded by the Japanese Ministry of Education, Culture, Sports, Science, and Technology (Grant-in-Aid for Young Scientists, No. 23710028) and the Japanese Forestry Agency (Emergency Project to Develop the Structure of Promoting REDD Action). The authors thank Drs. R. Wagai, Y. Yonekura, M. Yamaguchi, and M. Sakai for their valuable advice regarding the laboratory experiments. The authors are also deeply indebted to the staff members of the Soil Resources Laboratory, Forestry and Forest Products Research Institute, for the use of their laboratory to measure soil physical properties.

\section{References}

1. Blakemore, L.C. et al. (1987) Methods for Chemical Analysis of Soils, New Zealand Soil Bureau Scientific Report 80. New Zealand Soil Bureau, Lower Hutt.

2. Crocker, C.D. (1962) Exploratory Survey of the Soils of Cambodia. Royal Cambodian Government Soil Commission and US Agency for International Development, Phnom Penh.

3. Gee, G.W. \& Bauder, J.W. (1986) Particle-size analysis. In Methods of Soil Analysis, Part 1 Physical and Mineralogical Methods, ed. Klute, A.S., ASA \& SSSA, Madison, WI, 383-411.

4. Golchin, A. et al. (1994) Study of free and occluded particulate organic matter in soils by solid state $13 \mathrm{C} \mathrm{Cp/MAS}$ NMR spectroscopy and scanning electron microscopy. Aust. J. Soil Res., 32, 285-309.

5. IUSS Working Group WRB (2006) World Reference Base for Soil Resources 2006, 2nd ed., World Soil Resources Reports No. 103. FAO, Rome.

6. Kyuma, K. (1969) Reddish-colored soils in Southeast Asia, their distribution, genesis and classification. Tounan Asia Kenkyu (Southeast Asian Stud.), 7, 163-176 [In Japanese with English summary].

7. Nagata, T. (1943) Basalt soils of southern French Indochina. The bulletin of the Morioka College of Agriculture and Forestry, 16, 177-185 [In Japanese].

8. Ohnuki, Y. et al. (2008) Distribution and characteristics of soil thickness and effects upon water storage in forested areas of Cambodia. Hydrol. Process., 22, 1272-1280.

9. Saeki, H. et al. (1959) Investigations on Cambodian soils. Soil Sci. Plant Nutr., 5, 16-22.

10. Schafer, B.M. \& Mcgarity, J.W. (1980) Genesis of red and dark brown soils on basaltic parent materials near Armidale, N.S.W., Australia. Geoderma, 23, 31-47.
11. Shang, C. \& Tiessen, H. (1997) Organic matter lability in a tropical Oxisol: Evidence from shifting cultivation, chemical oxidation, particle size, density, and magnetic fractionations. Soil Sci., 162, 795-807.

12. Sollins, P. et al. (1996) Stabilization and destabilization of soil organic matter: mechanisms and controls. Geoderma, 74, 65-105.

13. Sumner, M.E. \& Miller, W.P. (1996) Cation exchange capacity and exchange coefficients. In Methods of Soil Analysis, Part 3 Chemical Methods, ed. Sparks, D.L., ASA \& SSSA, Madison, WI, 1201-1229.

14. Tani, A. et al. (2007) Principal forest types of three regions of Cambodia: Kampong Thom, Kratie, and Mondolkiri. In Forest environments in the Mekong River basin, eds. Sawada, H. et al., Springer, Tokyo, 201-213.

15. Toriyama, J. et al. (2010) Physicochemical characteristics of plinthic and non-plinthic soils in dry deciduous forests on the east bank of Mekong, Cambodia. Pedologist, 54, $2-10$.

16. Toriyama, J. et al. (2011) Soil carbon stock in Cambodian monsoon forests. JARQ, 45, 309-316.

17. Toriyama, J. et al. (2011) Soil pore characteristics of evergreen and deciduous forests of the tropical monsoon region in Cambodia. Hydrol. Process., 25, 714-726.

18. Tsutsumi, T. et al. (1966) The amount of plant nutrients and their circulation in forest soils in Thailand: carbon and nitrogen contents and some physical properties of the forest soils. Tounan Asia Kenkyu (Southeast Asian Stud.), 4, 327366 [In Japanese].

19. Tsutsumi, T. et al. (1967) The amount of plant nutrients and their circulation in forest soils in Thailand: the amount of bases, phosphorus and their circulation. Tounan Asia Kenkyu (Southeast Asian Stud.), 4, 897-928 [In Japanese].

20. Von Lützow, M. et al. (2007) SOM fractionation methods: Relevance to functional pools and to stabilization mechanisms. Soil Biol. Biochem., 39, 2183-2207.

21. Wagai, R. et al. (2008) Climate and parent material controls on organic matter storage in surface soils: A three-pool, density-separation approach. Geoderma, 147, 23-33.

22. Wakita, K. et al. (2004) Digital Geologic Map of East and Southeast Asia, Digital Geoscience Map G-2. Geological Survey of Japan, AIST, Tsukuba.

23. Workman, D.R. (1977) Geology of Laos, Cambodia, South Vietnam and the Eastern Part of Thailand, Overseas Geology and Mineral Resources No. 50. Institute of Geological Sciences, London.

24. Yonekura, Y. et al. (2010) Changes in soil carbon stock after deforestation and subsequent establishment of "Imperata" grassland in the Asian humid tropics. Plant Soil, 329, 495507.

25. Yuan, T.L. (1959) Determination of exchangeable hydrogen in soils by a titration method. Soil Sci., 88, 164-167. 